\title{
KAJIAN PERMASALAHAN PENGEMBANGAN \\ BUDIDAYA IKAN KERAPU DALAM KERAMBA JARING APUNG DI KABUPATEN SITUBONDO
}

\author{
Sri Sukari Agustina \\ Staf Pengajar Fakultas Perikanan UNISMUH Luwuk Kabupaten Banggai \\ Email :asrisukari@yahoo.com
}

\begin{abstract}
ABSTRAK
Penelitian ini bertujuan mengkaji dan menganalisis permasalahan pengembangan budidaya ikan kerapu dalam keramba jaring apung di Kabupaten Situbondo. Metode penelitian menggunakan metode survei. Pengumpulan data primer dengan cara observasi, penyebaran kuesioner, wawancara, dan FGD (Focus Group Dicussion). Pengumpulan data sekunder diperoleh dari berbagai instansi pemerintah yang terkait. Analisis data menggunakan analisis deskriptif kuantitatif dan analisis SWOT. Hasil penelitian menunjukkan bahwa permasalahan pengembangan budidaya ikan kerapu dalam keramba jaring apung di Kabupaten Situbondo yaitu (1) permasalahan mikro meliputi keterbatasan benih ikan kerapu ukuran gelondongan, kematian ikan kerapu disebabkan oleh penyakit, rendahnya manajemen kualitas air, keterbatasan pakan rucah, dan (2) permasalahan makro meliputi keterbatasan modal, rendahnya pengetahuan teknologi budidaya, dan keterbatasan mengakses pasar. Hasil analisis matriks IFE dan EFE diketahui bahwa posisi internal dan eksternal budidaya ikan kerapu dalam keramba jaring apung di Kabupaten Situbondo berada pada posisi kuadran I ( 2,746 ; 2,992), dimana kondisi ini merupakan situasi yang sangat menguntungkan. Usaha budidaya ikan kerapu dalam keramba jaring apung di Kabupaten Situbondo memiliki peluang dan kekuatan sehingga dapat memanfaatkan peluang yang ada dengan meminimalisir ancaman dan kelemahan.
\end{abstract}

Kata kunci: pengembangan budidaya, kerapu, keramba jaring apung 


\section{PENDAHULUAN}

Kabupaten Situbondo mempunyai potensi kelautan dan perikanan yang cukup besar. Dengan luas wilayah laut yang dikelola $1.142,4 \mathrm{~km}^{2}$ dan kedalaman wilayahnya dari pantai rata-rata $11 \mathrm{~m}$ (Dinas Kelautan dan Perikanan Kabupaten Situbondo, 2009), secara geografis sangat potensial untuk pengembangan usaha budidaya laut terutama budidaya ikan kerapu dalam keramba jaring apung.

Selain faktor di atas, harga ikan kerapu hidup yang tinggi dan permintaan ikan kerapu di Indonesia yang terus meningkat, baik untuk pasar domestik maupun ekspor, serta adanya BBAP (Balai Budidaya Air Payau) Situbondo yang mempunyai kegiatan dalam perekayasaan teknologi budidaya, semakin memberikan peluang kepada Kabupaten Situbondo untuk mengembangkan budidaya ikan kerapu dengan keramba jaring apung.

Usaha budidaya ikan kerapu dalam keramba jaring apung yang diusahakan secara semi intensif di Kabupaten Situbondo, merupakan pilihan yang sangat potensial untuk dikembangkan menjadi usaha yang lebih modern, maju dan memiliki daya saing mengingat peluang, potensi pasar dan perairannya yang luas. Namun potensi tersebut belum dimanfaatkan dan ditangani secara optimal dibandingkan dengan luas wilayahnya.

Berdasarkan laporan evaluasi pembangunan kelautan dan perikanan Dinas Kelautan dan Perikanan Kabupaten Situbondo, volume produksi ikan kerapu dengan keramba jaring apung di Kabupaten Situbondo pada tahun 2006 sebesar 125,22 ton, pada tahun 2007 sebesar 93,94 ton, sedangkan pada tahun 2008 sebesar 5,20 ton. Ikan kerapu yang dibudidayakan berupa ikan kerapu tikus dan kerapu macan, dengan ukuran benih tebar bervariasi antara 20-30 g/ekor dan lama pemeliharaan 7-12 bulan bergantung kepada jenis ikan dan ukuran benih tebar (Dinas Kelautan dan Perikanan Kabupaten Situbondo, 2006-2009).

Terjadinya penurunan volume produksi ikan kerapu dari tahun 2006 sampai tahun 2008 dalam budidaya ikan kerapu dengan keramba jaring apung di Kabupaten Situbondo banyak faktor yang menyebabkannya. Faktor-faktor ini meliputi permasalahan mikro dan permasalahan makro. Permasalahan mikro dan makro yang ada pada pengembangan budidaya ikan kerapu dalam keramba jaring apung di Kabupaten Situbondo memerlukan suatu kajian pengembangan budidaya.

Tujuan penelitian adalah mengkaji dan menganalisis permasalahan pengembangan budidaya ikan kerapu dalam keramba jaring apung di Kabupaten Situbondo.

\section{METODOLOGI PENELITIAN}

Penelitian ini dilaksanakan pada tanggal 23 Pebruari 2009 sampai dengan 30 April 2009 dengan lokasi penelitian wilayah perairan Klatakan Kecamatan Kendit dan perairan Gelung Kecamatan Panarukan Kabupaten Situbondo. Metode yang digunakan dalam penelitian ini yaitu metode survei. Metode pengambilan sampel responden menggunakan metode purposive sampling. Populasi dari penelitian adalah stakeholder, shareholder, penyuluh dan peneliti yang terkait dan 14 orang pembudidaya ikan kerapu dalam 
keramba jaring apung di Kabupaten Situbondo.

Data primer diperoleh dengan cara: 1) observasi langsung ke obyek penelitian; 2) penyebaran kuesioner dan wawancara dengan pembudidaya ikan kerapu dalam KJA; 3) wawancara dengan responden terpilih yang terkait budidaya ikan kerapu dalam KJA; dan 4) FGD (Focus Group Dicussion). Sedangkan data sekunder diperoleh dari BAPPEDA Kabupaten Situbondo, Dinas Kelautan dan Perikanan Kabupaten Situbondo dan dari BPS Kabupaten Situbondo. Data penelitian dan informasi yang telah terkumpul dianalisis secara deskriptif kuantitatif dan anallisis SWOT.

\section{HASIL DAN PEMBAHASAN}

Permasalahan pengembangan budidaya ikan kerapu dalam keramba jaring apung di Kabupaten Situbondo berupa permasalahan mikro dan permasalahan makro.

\section{A. Permasalahan Mikro}

\section{Keterbatasan benih ikan ukuran gelondongan}

Keterbatasan benih ukuran gelondongan merupakan kendala yang sangat penting dihadapi oleh pembudidaya baik dari kuantitas, kualitas maupun harga benih di Kabupaten Situbondo, sehingga untuk mengatasi kendala keterbatasan benih ikan kerapu ukuran gelondongan di Kabupaten Situbondo diperlukan pengaturan jadual pembudidaya dalam melakukan penebaran benih ikan kerapu ukuran gelondongan di keramba jaring apung.
2. Kematian ikan disebabkan oleh penyakit

Kematian ikan yang ditimbulkan oleh penyakit sering terjadi pada budidaya ikan kerapu dalam keramba jaring apung di lokasi perairan Klatakan Kecamatan Kendit dan perairan Gelung Kecamatan Panarukan. Hasil analisis laboratorium secara mikroskopis, didapatkan penyakit yang paling umum menyerang permukaan kulit ikan kerapu dalam keramba jaring apung di perairan Klatakan Kecamatan Kendit dan perairan Gelung Kecamatan Panarukan Kabupaten Situbondo adalah kutu kulit (skin flukes) seperti Benedenia spp., di air tawar nampak bulat berwarna putih dan secara visual penyakit ini dapat dilihat. Sedangkan yang biasa menyerang insang adalah cacing dari jenis Dactilogyrus sp., ikan yang terserang cacing ini akan terlihat pucat dan tampak berlendir. Pencegahan dan penanggulangan penyakit tersebut penting dilakukan dengan cara merendam ikan kerapu di air tawar lebih kurang 15 menit setiap minggu.

\section{Rendahnya manajemen kualitas air}

Pengamatan dan pengukuran kualitas air yang meliputi parameter fisika, kimia dan biologi dalam budidaya ikan kerapu dalam keramba jaring apung di Kabupaten Situbondo sangat penting dilakukan oleh pembudidaya. Namun sebagian pembudidaya belum pernah melakukan kecuali ada kegiatan penelitian yang pernah dilakukan oleh LAPAN pada tahun 2002 dan tahun 2004. 


\section{Keterbatasan pakan rucah}

Jenis-jenis ikan rucah yang dipergunakan pembudidaya untuk pakan ikan kerapu dalam keramba jaring apung di perairan Klatakan Kecamatan Kendit dan perairan Gelung Kecamatan Panarukan Kabupaten Situbondo pada umumnya ikan beloso, kurisi, kuniran, dan lemuru. Ketersediaan pakan rucah ini tergantung musim, apabila musim ikan harganya $\mathrm{Rp} 3.000,-/ \mathrm{kg}$ dan akan naik menjadi $\mathrm{Rp} 4.000,-/ \mathrm{kg}$ apabila suplai ikan rucah terbatas. Produksi ikan rucah ini melalui rantai pengadaan ikan rucah yang berkesinambungan (suplayer). Pada saat musim ombak, ikan rucah tidak ada sama sekali dan pembudidaya tidak memberi pakan, sebagian lagi dari pembudidaya memberi pakan buatan.

\section{B. Permasalahan Makro}

\section{Keterbatasan modal}

Produksi kerapu hidup melalui budidaya dalam keramba jaring apung memerlukan waktu lama 1 hingga 1,5 tahun, dan memerlukan modal yang besar dalam pengembangkan usaha. Pembudidaya dalam melaksanakan kegiatan usaha budidaya ikan kerapu, mengandalkan modal sendiri, sementara lembaga permodalan kurang berperan dalam membantu para pembudidaya untuk mendapatkan dukungan permodalan dan investasi.

\section{Rendahnya keterampilan dan} pengetahuan teknologi budidaya

$\begin{array}{rrr} & \text { Pembudidaya ikan kerapu } \\ \text { dalam keramba jaring apung }\end{array}$

di Kabupaten Situbondo memperoleh keterampilan dan pengetahuan teknologi budidaya ikan kerapu ada yang secara turun temurun, ada yang pernah mengikuti kegiatan pelatihan di BBAP Situbondo dan ada yang dari keahlian teknis pembudidaya sendiri. Ketidak tertarikan mereka pada pengetahuan teknologi budidaya disebabkan karena kekurangan modal dan kekhawatiran mereka dalam mencoba teknologi budidaya tetap tidak akan menambah penghasilan mereka. Kegiatan penyuluhan dan sosialisasi terhadap pengetahuan teknologi budidaya ikan kerapu dalam keramba jaring apung secara intensif yang dilakukan oleh BBAP Situbondo kepada pembudidaya ikan kerapu sangat membantu dalam meningkatkan keterampilan dan pengetahuan teknologi budidaya mereka.

\section{Keterbatasan mengakses pasar}

Hasil produksi ikan kerapu dari usaha budidaya keramba jaring apung Kabupaten Situbondo dijual ke Jakarta, Surabaya, Bali dan Hongkong, ikan kerapu tikus harganya Rp 350.000,-Rp 400.000,-/kg, ikan kerapu macan Rp 100.000,--Rp 130.000,-/kg. Belum adanya jaminan pasar tentang harga ikan kerapu hidup ukuran konsumsi baik lokal maupun ekspor dari pemerintah merupakan permasalahan bagi pembudidaya.

Tabel 1 merupakan hasil identifikasi faktor internal dan eksternal yang mempengaruhi pengembangan budidaya ikan kerapu dalam keramba jaring apung di Kabupaten Situbondo. 
Tabel 1. Hasil identifikasi faktor internal dan eksternal

\begin{tabular}{|c|c|}
\hline FAKTOR INTERNAL & FAKTOR EKSTERNAL \\
\hline $\begin{array}{l}\text { KEKUATAN (STRENGHTS) } \\
\text { 1. Posisi geografis yang strategis } \\
\text { 2. Potensi perikanan budidaya tinggi } \\
\text { 3. Lahan budidaya tersedia } \\
\text { 4. }\end{array}$ & $\begin{array}{ll}\text { PELUANG (OPPORTUNITIES) } \\
\text { 1. Harga ikan kerapu tinggi } \\
\text { 2. } & \text { Permintaan pasar terbuka luas } \\
\text { 3. } & \text { Pendapatan masyarakat pesisir } \\
& \text { meningkat } \\
\text { 4. } & \text { Penyerapan tenaga kerja } \\
\text { 5. } & \text { Otonomi Daerah } \\
\text { 6. } & \text { RTRW/RTWRPL/Rencana Zonasi } \\
& \text { Kabupaten Situbondo } \\
\text { 7. } & \text { Kebijakan Nasional dalam } \\
& \text { pengembangan perikanan }\end{array}$ \\
\hline KELEMAHAN (WEAKNESSES) & ANCAMAN (THREATS) \\
\hline $\begin{array}{l}\text { 1. Keterbatasan benih ukuran } \\
\text { gelondongam }\end{array}$ & $\begin{array}{l}\text { 1. Perubahan iklim/musim } \\
\text { 2. Belum adanya jaminan pasar }\end{array}$ \\
\hline $\begin{array}{l}\text { 2. Kematian ikan disebabkan oleh } \\
\text { penyakit }\end{array}$ & $\begin{array}{l}\text { 3. Penentuan standar mutu produk } \\
\text { budidaya }\end{array}$ \\
\hline Rendahnya manajemen kualitas air & Rendahnya dukungan permodalan \\
\hline Keterbatasan pakan rucah & 5. Keamanan \\
\hline Keterbatasan modal & Adanya pencemaran lingkungan \\
\hline $\begin{array}{l}\text { 6. Rendahnya keterampilan \& } \\
\text { pengetahuan teknologi budidaya } \\
\text { 7. Keterbatasan mengakses pasar }\end{array}$ & $\begin{array}{l}\text { 7. Kurangnya penegakan regulasi } \\
\text { RTRW untuk pengembangan } \\
\text { budidaya perikanan }\end{array}$ \\
\hline
\end{tabular}

\section{External Factor Evaluation (EFE) Matriks}

EFE matriks digunakan untuk mengetahui dan mengevaluasi faktor eksternal kegiatan budidaya. Hasil analisis penilaian terhadap faktor eksternal budidaya ikan kerapu dalam keramba jaring apung di Kabupaten Situbondo disajikan pada Tabel 4.

Tabel 2. EFE matriks budidaya ikan kerapu dalam KJA

\begin{tabular}{|c|c|c|c|c|}
\hline & ASPEK-ASPEK & Bobot & Rating & Skor \\
\hline \multicolumn{5}{|c|}{ PELUANG } \\
\hline 1. & Harga ikan kerapu tinggi & 0,114 & 3,7 & 0,422 \\
\hline 2. & Permintaan pasar terbuka luas & 0,103 & 3,6 & 0,371 \\
\hline 3. & Pendapatan masyarakat pesisir meningkat & 0,075 & 3,1 & 0,233 \\
\hline 4. & Penyerapan tenaga kerja & 0,074 & 3,1 & 0,230 \\
\hline 5. & Otonomi Daerah & 0,073 & 3,0 & 0,220 \\
\hline \multirow[t]{2}{*}{6.} & RTRW/RTWRPL/Rencana Zonasi & 0,075 & 3,2 & 0,240 \\
\hline & Kabupaten Situbondo & & & \\
\hline \multirow[t]{3}{*}{7.} & Kebijakan Nasional dalam & 0,072 & 3,1 & 0,223 \\
\hline & & & & 1,939 \\
\hline & ANCAMAN & & & \\
\hline 1. & Perubahan iklim/musim & 0,085 & 2,1 & 0,179 \\
\hline 2. & Belum adanya jaminan pasar & 0,050 & 3,3 & 0,165 \\
\hline 3. & Penentuan standar mutu produk budidaya & 0,059 & 2,6 & 0,153 \\
\hline 4. & Rendahnya dukungan permodalan & 0,066 & 2,0 & 0,132 \\
\hline 5. & Keamanan & 0,061 & 2,3 & 0,140 \\
\hline 6. & Adanya pencemaran lingkungan & 0,043 & 3,0 & 0,129 \\
\hline \multirow[t]{3}{*}{7.} & Kurangnya penegakan regulasi RTRW & 0,050 & 3,1 & 0,155 \\
\hline & & & & 1,053 \\
\hline & PENILAIAN & 1,00 & & 2,992 \\
\hline
\end{tabular}

Hasil analisis EFE matriks di atas menunjukkan penilaian faktor-faktor peluang mendapat skor 1,939 dan faktorfaktor ancaman mendapat skor 1,053, dimana skor peluang yang ada pada budidaya budidaya ikan kerapu dalam keramba jaring apung di Kabupaten Situbondo lebih besar daripada ancamannya. Pembudidaya ikan kerapu dalam keramba jaring apung di Kabupaten Situbondo dapat menjalankan kegiatan usahanya dengan memanfaatkan peluang yang ada, namun tetap waspada terhadap ancaman yang datang. Jumlah skor keseluruhan faktor eksternal budidaya ikan sebesar 2,992, secara keseluruhan kondisi eksternal cukup berpeluang untuk mendukung upaya pengembangan budidaya ikan kerapu dalam keramba jaring apung di Kabupaten Situbondo. David (2006) menyatakan dalam matriks EFE total nilai tertimbang tertinggi adalah 4,0 dan terendah adalah 1,0 dengan total nilai tertimbang rata-rata 2,5. Skor total perkalian bobot dan rating berjumlah 4,0 mengindikasikan bahwa strategi perusahaan secara efektif mengambil keuntungan dari peluang yang ada saat ini dan meminimalkan efek yang mungkin muncul dari ancaman eksternal. Skor total sebesar 1,0 menunjukkan bahwa strategi perusahaan tidak memanfaatkan peluang yang ada atau tidak menghindari ancaman eksternal.

\section{Internal Factor Evaluation (IFE) Matriks}

IFE Matriks digunakan untuk mengetahui dan mengevaluasi faktor-faktor internal perusahaan. Hasil analisis penilaian terhadap faktor-faktor internal budidaya ikan kerapu dalam keramba jaring apung 
di Kabupaten Situbondo disajikan pada Tabel 3.

Tabel 3. IFE Matriks budidaya ikan kerapu dalam KJA

\begin{tabular}{|c|c|c|c|c|}
\hline & ASPEK-ASPEK & Bobot & Rating & Skor \\
\hline \multicolumn{5}{|c|}{ KEKUATAN } \\
\hline 1. & Posisi geografis yang strategis & 0,134 & 3,4 & 0,456 \\
\hline 2. & Potensi perikanan budidaya tinggi & 0,133 & 3,0 & 0,399 \\
\hline 3. & Lahan budidaya tersedia & 0,129 & 2,9 & 0,374 \\
\hline \multirow[t]{3}{*}{4} & Tenaga kerja tersedia & 0,122 & 2,9 & 0,354 \\
\hline & & & & 1,583 \\
\hline & KELEMAHAN & & & \\
\hline 1. & Keterbatasan benih ukuran gelondongan & 0,079 & 2,1 & 0,166 \\
\hline 2. & Kematian ikan disebabkan oleh penyakit & 0,078 & 2,6 & 0,203 \\
\hline 3. & Rendahnya manajemen kualitas air & 0,063 & 2,1 & 0,132 \\
\hline 4. & Keterbatasan pakan rucah & 0,069 & 1,8 & 0,124 \\
\hline 5. & Keterbatasan modal & 0,082 & 2,5 & 0,205 \\
\hline 6. & $\begin{array}{l}\text { Rendahnya keterampilan \& pengetahuan } \\
\text { teknologi budidaya }\end{array}$ & 0,057 & 3,0 & 0,171 \\
\hline \multirow[t]{3}{*}{7.} & Keterbatasan mengakses pasar & 0,054 & 3,0 & 0,162 \\
\hline & & & & 1,163 \\
\hline & PENILAIAN & 1,00 & & 2,746 \\
\hline
\end{tabular}

Hasil analisis IFE matriks di atas menunjukkan penilaian faktor-faktor kekuatan mendapat skor 1,583 dan faktorfaktor kelemahan mendapat skor 1,163, skor kekuatan yang ada pada budidaya ikan kerapu lebih besar daripada kelemahannya. Pembudidaya ikan kerapu dalam keramba jaring apung di Kabupaten Situbondo dapat menjalankan kegiatan usahanya dengan memanfaatkan kekuatan yang ada dan meminimalisir kelemahan. Total skor budidaya ikan kerapu dalam keramba jaring apung sebesar 2,746, secara keseluruhan kondisi internal cukup kuat untuk mendukung upaya pengembangan budidaya ikan kerapu dalam keramba jaring apung di Kabupaten Situbondo. David (2006) menyatakan bahwa skor total perkalian bobot dan rating berjumlah 2,5 mempunyai nilai rata-rata. Jika nilainya di bawah 2,5 menandakan secara internal perusahaan adalah lemah, sedangkan nilai yang berada di atas 2,5 menunjukkan posisi internal yang kuat.
Hasil analisis matriks IFE dan EFE dapat diketahui bahwa posisi internal dan eksternal budidaya ikan kerapu dalam keramba jaring apung di Kabupaten Situbondo berada pada posisi kuadran I ( 2,746; 2,992 ), yang disajikan pada Gambar berikut:

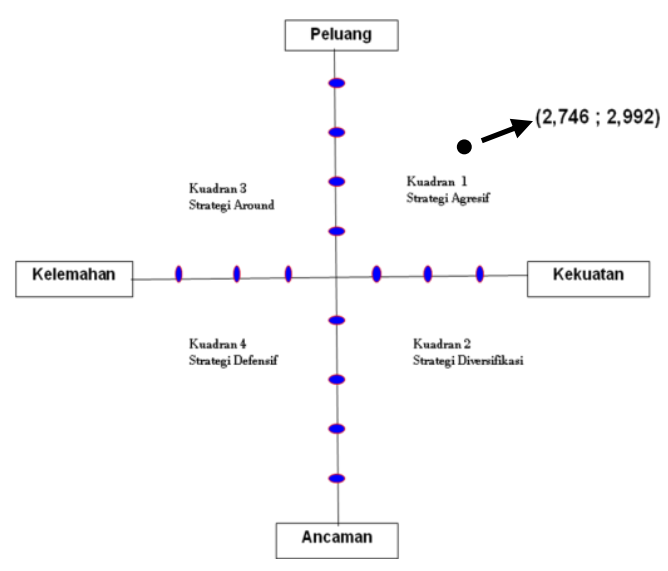

\section{Gambar: Grafik Kuadran SWOT}

Kondisi ini merupakan situasi yang sangat menguntungkan. Usaha budidaya ikan kerapu dalam keramba jaring apung di Kabupaten Situbondo memiliki peluang dan kekuatan sehingga dapat memanfaatkan peluang yang ada dengan meminimalisir ancaman-ancaman dan kelemahan-kelemahan yang ada. Rangkuti (2006), menjelaskan apabila posisi internal dan eksternal berada di kuadran I, maka strategi yang harus ditetapkan dalam kondisi ini adalah mendukung kebijakan pertumbuhan yang agresif (growth oriented strategy). Artinya pembudidaya ikan kerapu, pemerintah, perbankan dan investor mulai dari sekarang harus agresif dalam menjalankan, memperkuat dan mendukung pertumbuhan usaha budidaya ikan kerapu dalam keramba jaring apung di Kabupaten Situbondo. 


\section{Matriks SWOT}

Tersusunnya matriks EFE dan IFE di atas kemudian dirangkum dalam matriks SWOT untuk memberikan rumusan alternatif strategi yang sesuai bagi kondisi fisik. Matriks SWOT dapat menggambarkan secara jelas bagaimana peluang dan ancaman eksternal yang dihadapi perusahaan dapat disesuaikan dengan kekuatan dan kelemahan yang dimilikinya. Penyusunan rumusan strategi masing-masing faktor matriks EFE dan IFE dalam matriks SWOT disajikan pada Tabel 4.

Tabel 4. Matriks SWOT budidaya ikan kerapu dalam keramba jaring apung di Kabupaten Situbondo

\begin{tabular}{|c|c|c|c|c|c|}
\hline & EFE & 4 & $\begin{array}{l}\quad \text { KEKUATAN (STRENGHTS) } \\
\text { Posisi geografis yang strategis } \\
\text { Potensi perikanan budidaya tinggi } \\
\text { Lahan budidaya tersedia } \\
\text { Tenaga kerja tersedia }\end{array}$ & $\begin{array}{l}2 \\
3 \\
4 \\
5\end{array}$ & $\begin{array}{l}\quad \text { KELEMAHAN ( } \text { WEAKNESSES) } \\
\text { Keterbatasan benih ukuran gelondongan } \\
\text { Kematian ikan disebakan oleh penyakit } \\
\text { Rendahnya manajemen kualitas air } \\
\text { Keterbatasan pakan rucah } \\
\text { Keterbatasan modal } \\
\text { Rendahnya keterampilan \& pengetahuan } \\
\text { teknologi budidaya } \\
\text { Keterbatasan mengakses pasar }\end{array}$ \\
\hline $\begin{array}{l}5 \\
6\end{array}$ & $\begin{array}{l}\text { PELUANG (OPPORTUNITIES) } \\
\text { Harga ikan kerapu tinggi } \\
\text { Permintaan pasar terbuka luas } \\
\text { Pendapatan masyarakat pesisir meningkat } \\
\text { Penyerapan tenaga kerja } \\
\text { Otonomi Daerah } \\
\text { RTRW/RTWRPL/Rencana Zonasi } \\
\text { Kabupaten Situbondo } \\
\text { Kebijakan Nasional dalam pengembangan } \\
\text { perikanan }\end{array}$ & 2 & $\begin{array}{l}\text { STRATEGI SO } \\
\text { Peningkatan kapasitas produksi melalui } \\
\text { intensifikasi usaha budidaya ikan kerapu } \\
\text { dalam keramba jaring apung } \\
\left(\mathrm{S}_{1},{ }_{2}, 3,{ }_{4} \& \mathrm{O}_{1}, 2,{ }_{3}, 4,5,6,7\right) \\
\text { Peningkatan pasar ekspor melalui } \\
\text { peningkatan promosi kualitas produk } \\
\text { hasil budidaya }\left(\mathrm{S}_{1},{ }_{2},{ }_{3},{ }_{4} \& \mathrm{O}_{1}, 2,3,4,7\right)\end{array}$ & 2 & $\begin{array}{l}\text { STRATEGI WO } \\
\text { Pengadaan benih ikan kerapu ukuran gelondongan } \\
\text { yang bermutu dan bersertifikasi }\left(\mathrm{W}_{1} \& \mathrm{O}_{1},{ }_{2},{ }_{3},{ }_{4}\right) \\
\text { Peningkatan kemampuan penguasaan teknologi } \\
\text { budidaya, manajemen kualitas air dan manajemen } \\
\text { pemberian pakan kepada pelaku usaha } \\
\left(\mathrm{W}_{2},{ }_{3},{ }_{4},{ }_{6}, 7 \text { \& } \mathrm{O}_{1}, 2,{ }_{3},{ }_{4}, 7\right)\end{array}$ \\
\hline $\begin{array}{l}3 \\
4 \\
5\end{array}$ & $\begin{array}{l}\quad \text { ANCAMAN (THREATS) } \\
\text { Perubahan iklim/musim } \\
\text { Belum adanya jaminan pasar } \\
\text { Penentuan standar mutu produk budidaya } \\
\text { Rendahnya dukungan permodalan } \\
\text { Keamanan } \\
\text { Adanya pencemaran lingkungan } \\
\text { Kurangnya penegakan regulasi RTRW } \\
\text { untuk pengembangan budidaya perikanan }\end{array}$ & 1 & $\begin{array}{l}\text { STRATEGI ST } \\
\text { Memilih perairan yang aman dari pengaruh } \\
\text { musim dan aktifitas lain } \\
\left(\mathrm{S}_{1},{ }_{2},{ }_{3}, 4 \text { \& } \mathrm{T}_{1},{ }_{5},{ }_{6,7}\right) \\
\text { Peningkatan peran DKP dalam melakukan } \\
\text { penjaminan mutu produk ikan budidaya } \\
\text { melalui sertifikasi terhadap produk } \\
\left(\mathrm{S}_{2} \& \mathrm{~T}_{2},{ }_{3}\right) \\
\text { Peningkatan sosialisasi RTRW Kabupaten } \\
\text { Situbondo kepada masyarakat }\left(\mathrm{S}_{3,4} \& \mathrm{~T}_{7}\right)\end{array}$ & 1 & $\begin{array}{l}\text { STRATEGI WT } \\
\text { Peningkatan peran lembaga permodalan melalui } \\
\text { lembaga perbankan dan koperasi nelayan juga } \\
\text { mitra usaha }\left(\mathrm{W}_{5}, \mathrm{~T}_{4}\right) \\
\text { Pembentukan asosiasi pembudidaya ikan kerapu } \\
\text { dalam rangka mendapatkan dukungan/bantuan } \\
\text { teknis dan non teknis dari institusi Perguruan } \\
\text { Tinggi, Dinas Teknis dan perbankan } \\
\left(\mathrm{W}_{5,7} \& \mathrm{~T}_{2}, 3,4,5,6,7,\right)\end{array}$ \\
\hline
\end{tabular}

Sumber : Data primer diolah (2009) 


\section{KESIMPULAN}

Berdasarkan hasil penelitian dapat diambil kesimpulan bahwa:

1. Permasalahan pengembangan budidaya ikan kerapu dalam keramba jaring apung di Kabupaten Situbondo yaitu permasalahan mikro meliputi keterbatasan benih ikan kerapu ukuran gelondongan, kematian ikan kerapu disebabkan oleh penyakit, rendahnya manajemen kualitas air, keterbatasan pakan rucah, sedangkan permasalahan makro meliputi keterbatasan modal, rendahnya pengetahuan teknologi budidaya, dan keterbatasan mengakses pasar.

2. Hasil analisis matriks IFE dan EFE diketahui bahwa posisi internal dan eksternal budidaya ikan kerapu dalam keramba jaring apung di Kabupaten Situbondo berada pada posisi kuadran I ( 2,$746 ; 2,992$ ), dimana kondisi ini merupakan situasi yang sangat menguntungkan. Usaha budidaya ikan kerapu dalam keramba jaring apung di Kabupaten Situbondo memiliki peluang dan kekuatan sehingga dapat memanfaatkan peluang yang ada dengan meminimalisir ancaman dan kelemahan.

\section{SARAN}

Berdasarkan hasil studi, sebaiknya studi ini disarankan untuk ditindaklanjuti oleh instansi yang terkait di Kabupaten Situbondo.

\section{DAFTAR PUSTAKA}

Akbar, S dan Sudaryanto, 2002. Pembenihan dan Pembesaran Kerapu Bebek. Penebar Swadaya. Jakarta. 104 hlm.
Arikunto, S. 2002. Prosedur Penelitian: Suatu Pendekatan Praktek. Rineka Cipta. Jakarta. 342 hlm.

Basmi, J. 2000. Planktonologi : Plankton Sebagai Indikator Kualitas Perairan. Fakultas Perikanan dan Ilmu Kelautan. Institut Pertanian Bogor.60 hlm.

Dinas Kelautan dan Perikanan Kabupaten Situbondo. 2003-2009. Laporan Evaluasi Pembangunan Kelautan dan Perikanan. Pemerintah Kabupaten Situbondo.

Ditjen Perikanan Budidaya. 2005. Petunjuk Teknis Budidaya Laut Ikan Kerapu (Epinephelus sp. dan Cromileptes altivelis). Direktorat Pembudidayaan. Direktorat Jenderal Perikanan Budidaya. Jakarta. $51 \mathrm{hlm}$.

Dwiyanto, F.S. dan Suriawan, A. 2006. Petunjuk Teknis Budidaya Kerapu di Keramba Jaring Apung. Departemen Kelautan dan Perikanan. Direktorat Jenderal Perikanan Budidaya. Balai Budidaya Air Payau Situbondo. $32 \mathrm{hlm}$.

Hanggono B. 2007. Manajemen Lingkungan dan Kualitas Air. Disajikan Pada Pelatihan Pembenihan Ikan Kerapu Di BBAP Situbondo tanggal 21-26 Mei 2007. Kerjasama Antara Balai Budidaya Air Payau Situbondo dengan Jafan International Cooperation Agency (JICA). Direktorat Jenderal Peikanan Budidaya Departemen Kelautan dan Perikanan. Situbondo. 120 hlm.

Kordi, M.G.H. 2007. Budidaya Kerapu Macan, Biologi, Pembenihan dan Pembesaran. CV Aneka Ilmu. Semarang. $183 \mathrm{hlm}$. 
Lampiran III Keputusan Menteri Negara Lingkungan Hidup Nomor 51 Tahun 2004 Tentang Baku Mutu Air Laut Untuk Biota Laut. <http://www.proxsis.com/ perundangan/LH/doc/uu/LAMP 3 KEPMEN No.51TH 2004.pdf.> Akses tanggal 22 Mei 2009.

Nazir, M. 2003. Metode Penelitian. Ghalia Indonesia. Jakarta. $542 \mathrm{hlm}$.

Nazam, M. 2004. Analisis Aspek Lingkungan Usaha Pembesaran Ikan Dalam Keramba Jaring Apung (Kasus di Teluk Ekas, Lombok Timur). Balai Pengkajian Teknologi Pertanian. NTB.

<ntb.litbang.deptan.go.id/2004/SP/ analisisaspek.doc>

Akses tanggal 22 Mei 2009

Radiarta, N., Saputra, A., Haryadi J. dan Prihadi H.T. 2006. Pemilihan lokasi Budidaya Ikan Dalam Keramba Jaring Apung Menggunakan Analisis Multi Kriteria dan Sistem Informasi Geografis di Teluk Kapontori, Sulawesi Tenggara. Jurnal Penelitian Perikanan Indonesia Vol. 1 No. 3 Tahun 2006: 337-348.

Rangkuti, F. 2006. Analisis SWOT Teknik Membedah Kasus Bisnis. Reorientasi Konsep Perencanaan Strategis Untuk Menghadapi Abad 2001. PT Gramedia Pustaka Utama. Jakarta. $188 \mathrm{hlm}$.

Sim, S.Y., Rimmer, M.A., Toledo, J.D., Sugama, K., Rumengan, I., Williams, K.C., Phillips, M.J. 2005. Pedoman Praktis Pemberian dan Pengelolaan Pakan Untuk Ikan Kerapu Yang Dibudidaya. NACA, Bangkok, Thailand. Publikasi No. 2005-02 dari Asia-Pacific Marine Finfish Aquaculture Network. 18 hlm.
Sudradjat, A. 2008. Budidaya 23 Komoditas Laut Menguntungkan. Penebar Swadaya. Jakarta. 171 hlm. 